\title{
STRUCTURE AND PROPERTIES OF EB- AND TIG-WELDED JOINTS OF HIGH-STRENGTH TWO-PHASE TITANIUM ALLOYS
}

\author{
S.V. AKHONIN, V.Yu. BELOUS, R.V. SELIN, I.K. PETRICHENKO and E.L. VRZHIZHEVSKY \\ E.O. Paton Electric Welding Institute, NASU \\ 11 Bozhenko Str., 03680, Kiev, Ukraine. E-mail: office@paton.kiev.ua
}

\begin{abstract}
Modern two-phase high-alloyed alloys based on titanium are characterized by a high specific strength. The thermal cycle of welding results in change of structures of weld and HAZ metal and also in deterioration of mechanical characteristics of the joint. In the work the properties of welded joints of titanium alloys VT23, T110 and high-alloyed alloy $\mathrm{Ti}-6.5 \mathrm{Al}-3 \mathrm{Mo}-2.5 \mathrm{~V}-4 \mathrm{Nb}-1 \mathrm{Cr}-1 \mathrm{Fe}-2.5 \mathrm{Zr}$, produced using electron beam and argon arc welding, were evaluated. In weld and HAZ metal of the TIG-welded joints of alloy $\mathrm{Ti}-6.5 \mathrm{Al}-3 \mathrm{Mo}-2.5 \mathrm{~V}-4 \mathrm{Nb}-1 \mathrm{Cr}-1 \mathrm{Fe}-2.5 \mathrm{Zr}$, the structure is formed with a predominance of metastable $\beta$-phase and low values of strength and impact toughness, the joints require postweld high-temperature annealing at temperature of not less than $900{ }^{\circ} \mathrm{C}$. The joints of VT23 alloy have high values of strength and impact toughness. High-strength titanium alloy T110 is characterized by good weldability in EBW and TIG welding, has high values of impact toughness of weld metal and HAZ after annealing, the strength of welded joints is at the level of 0.9 of base metal strength. 7 Ref., 2 Tables, 4 Figures.
\end{abstract}

Key words: titanium alloys, tungsten-electrode ar gon-arc welding, electron beam welding, properties

Modern two-phase high-alloyed alloys based on titanium are characterized by a high specific strength, nowadays the growing attention is paid to widening the use of welded structures and assemblies of high-strength titanium alloys $\left(\sigma_{t}>\right.$ $>1100 \mathrm{MPa})[1,2]$. The weldability of twophase high-alloyed titanium alloys, the use of which may provide the greatest reduction in mass of the structure, is significantly worse than that of low-alloyed alloys, and according to this indicator they are inferior even to some highstrength steels, therefore, when developing new titanium alloys, a significant attention is paid to the possibility of producing welded joints with strength of not less than $0.90-0.95$ of base material strength.

The aim of the work is to evaluate the properties of welded joints of both industrial and also new two-phase high-titanium alloys having $\sigma_{t}>$ $>1000 \mathrm{MPa}$ (Table 1), developed at the E.O.
Paton Electric Welding Institute, as well as to study the influence of thermal cycle of welding and postweld heat treatment on structural and phase transformations in weld metal and HAZ.

In the course of investigations the properties of welded joints, produced by electron beam welding (EBW) and argon arc welding with tungsten electrode (TIG) without using filler metal were compared.

The joints of high-strength titanium alloy VT23 [3] were made of $10 \mathrm{~mm}$ thick plates, joints of titanium alloy of grade T110 were made of $7 \mathrm{~mm}$ thick plates. The high-grade alloy of T110 system $\mathrm{Ti}-5.5 \mathrm{Al}-1.2 \mathrm{Mo}-1.2 \mathrm{~V}-4 \mathrm{Nb}-2 \mathrm{Fe}-0.5 \mathrm{Zr}$ was developed at the PWI together with the O.K. Antonov ASTC [4]. It contains the following alloying elements, wt.\%: 5-6 Al, 3.5-4.8 Nb, 0.8-1.8 Mo, 0.8-2 V, 1.5-2.5 Fe, 0.3-0.8 Zr. Alloy T110, as compared to VT23, has a higher resistance to the formation of fatigue cracks and according to the number of service characteristics, such as fatigue life of base metal (BM), exceeds the values of VT23 alloy by 15-20 \% [5].

Table 1. Mechanical properties of high-strength two-phase titanium alloys

\begin{tabular}{||l|c|c|c|c|c|c||}
\hline \hline \multicolumn{1}{|c|}{ Grade of alloy } & $\begin{array}{c}\text { Equivalent of } \\
\text { molybdenum }\end{array}$ & $\begin{array}{c}\text { Thickness of } \\
\text { metal, mm }\end{array}$ & $\sigma_{\mathrm{t}}, \mathrm{MPa}$ & $\sigma_{0.2}, \mathrm{MPa}$ & $\delta, \%$ & $K C V, \mathrm{~J} / \mathrm{cm}^{2}$ \\
\hline VT23 & $5.7-8.0$ & 10 & 1030 & 980 & 13 & 35 \\
\hline T110 & $4.4-7.9$ & 7 & 1190 & 1150 & 18 & 31 \\
\hline Ti-6.5Al-3Mo-2.5V-4Nb-1Cr-1Fe-2.5Zr & $5.6-10.5$ & 8 & 1195 & 1110 & 15 & 13 \\
\hline
\end{tabular}


Also the properties of welded joints of pilot high-alloyed alloy of 8-component system $\mathrm{Ti}-$ $6.5 \mathrm{Al}-3 \mathrm{Mo}-2.5 \mathrm{~V}-4 \mathrm{Nb}-1 \mathrm{Cr}-1 \mathrm{Fe}-2.5 \mathrm{Zr}$ were evaluated. It contains more alloying elements as compared to alloy T110 and in the state after annealing it has tensile strength exceeding $1200 \mathrm{MPa}$. The joints of this alloy of $8 \mathrm{~mm}$ thickness were produced using EBW and TIG method.

TIG was performed on both sides using tungsten electrode of $5 \mathrm{~mm}$ diameter in argon without filler metal. The welding current was 300-350 A, welding speed $-10 \mathrm{~m} / \mathrm{h}$. EBW was conducted in installation UL-144, completed with power source ELA $60 / 60$. The accelerating voltage was $60 \mathrm{kV}$, welding speed $25 \mathrm{~m} / \mathrm{h}$. The examples of produced welded joints are shown in Figure 1.

Immediately after welding VT23 weld metal produced using TIG welding represents the coarse primary $\beta$-grains, the intragranular structure of weld metal is characterized by martensite $\alpha^{\prime \prime}$-phase [2]. In order to improve the ductile characteristics of VT23 welded joints the simplest way is postweld heat treatment - annealing [6]. After heat treatment the structure is characterized by presence of fine-dispersed decay products of metastable phases with formation of equilibrium $\alpha^{-}$and $\beta$-phases, however, the strength of welded joint after annealing decreases to level lower than $1000 \mathrm{MPa}$.

The metal of $\mathrm{T} 110$ welds, produced using EBW, consists of $\beta$-grains equiaxial and elongated in the direction of heat dissipation ( $\mathrm{Fi}$ gure $2, a$ ), inside which uniform decay of solid solution with precipitation of dispersed particles of martensitic $\alpha^{\prime}$-phase is observed [7]. In the near-weld area the grain of primary $\beta$-phase is finer.

The microstructure of TIG-welded joints of alloy T110 is not essentially differed from the microstructure of the joints made by EBW. The metal of welds and near-weld areas of joints produced using TIG method has a structure of $\beta$ transformed grain with precipitation of fine acicular martensite $\alpha^{\prime}$-phase. In the areas of HAZ metal adjacent to BM, except of the mentioned structural elements inside the grains, a primary coarse lamellar $\alpha$-phase is observed. The joints made by TIG welding have also an identical structure. The joints made by EBW have a considerably smaller structurally modified fusion zone and HAZ as compared to the joints made using tungsten electrode. The strength of welds, produced using TIG method and EBW, is at the same level. For the joints in EBW, a typical place for fracture of rupture specimens is BM, and for TIG welding is weld. After welding, EB-

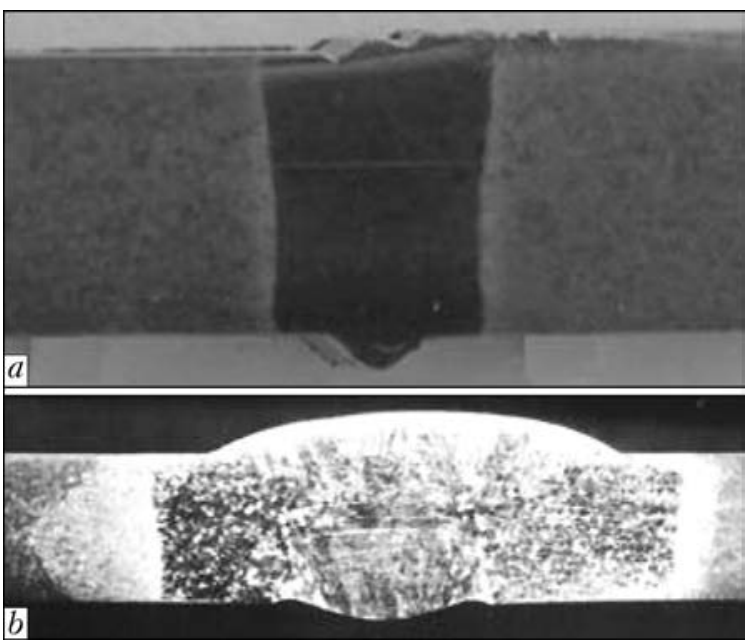

Figure 1. Transverse macrosection of EB- $(a)$ and TIGwelded $(b)$ joint of titanium alloy $\mathrm{Ti}-6.5 \mathrm{Al}-3 \mathrm{Mo}-2.5 \mathrm{~V}-$ $4 \mathrm{Nb}-1 \mathrm{Cr}-1 \mathrm{Fe}-2.5 \mathrm{Zr}$ of $8 \mathrm{~mm}$ thickness

welded joints have a strength equal or higher than that of BM, and the strength of TIG-welded joints is at the level of $0.9 \%$ of the strength of alloy itself; annealing at $750{ }^{\circ} \mathrm{C}$ with subsequent furnace cooling results in a further decrease in strength of welded joints, but the values of impact toughness are increased to $30 \mathrm{~J} / \mathrm{cm}^{2}$ for the joints made by arc welding. In order to increase the impact toughness of joints made by EBW it is necessary to apply a higher-temperature annealing - at $850{ }^{\circ} \mathrm{C}$. After this annealing the decay of metastable phases occurs with the predominance of lamellar $\alpha$-phase (Figure 2,b), the

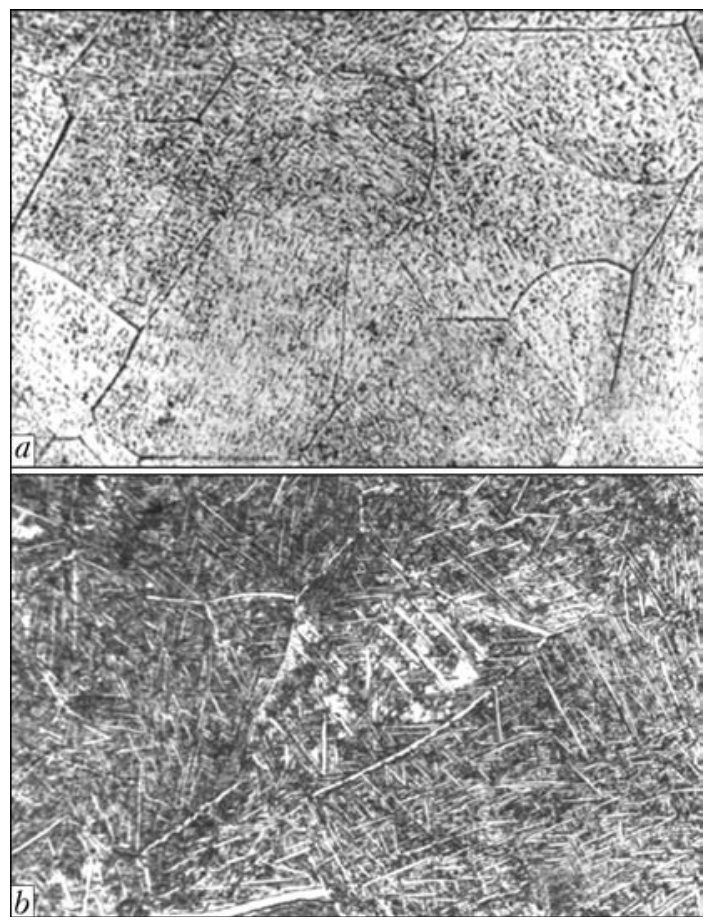

Figure 2. Microstructure $(\times 400)$ of weld metal of EBwelded joint of titanium alloy T110: $a-$ after welding; $b$ - after annealing at $750{ }^{\circ} \mathrm{C}$ for $1 \mathrm{~h}$ 


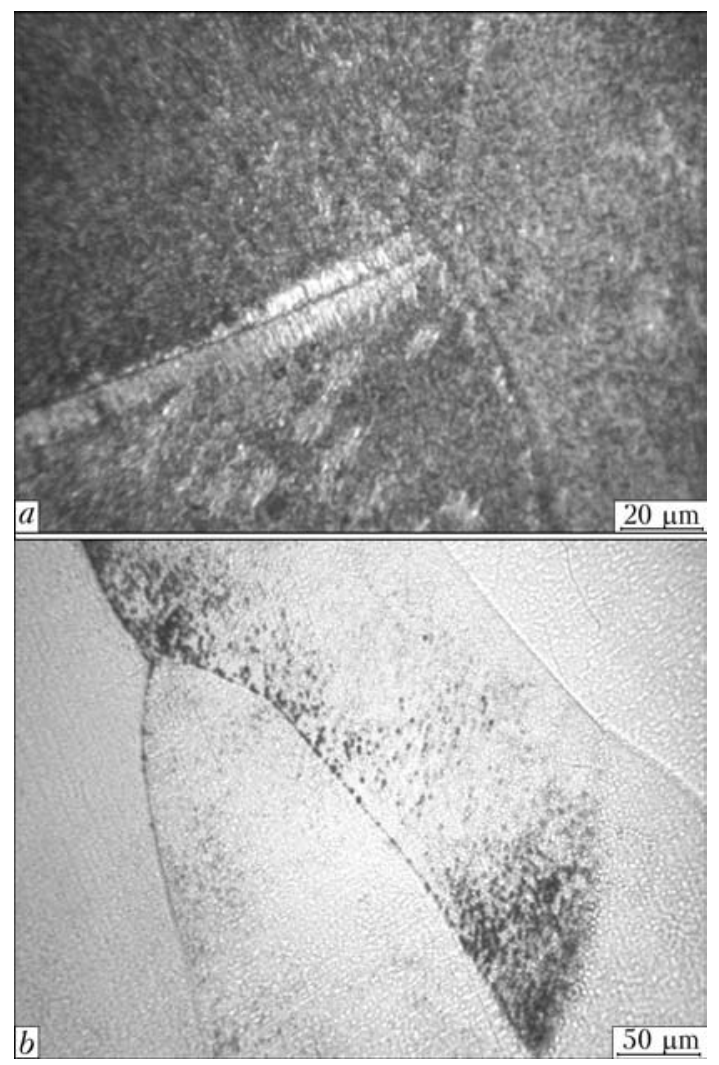

Figure 3. Microstructure of weld metal of titanium alloy $\mathrm{Ti}-6.5 \mathrm{Al}-3 \mathrm{Mo}-2.5 \mathrm{~V}-4 \mathrm{Nb}-1 \mathrm{Cr}-1 \mathrm{Fe}-2.5 \mathrm{Zr}$ produced by EBW: $a-\mathrm{BM} ; b-$ weld metal after welding

parameters of which contribute to increase of toughness at a high level of strength.

High-alloyed alloy $\mathrm{Ti}-6.5 \mathrm{Al}-3 \mathrm{Mo}-2.5 \mathrm{~V}-$ $4 \mathrm{Nb}-1 \mathrm{Cr}-1 \mathrm{Fe}-2.5 \mathrm{Zr}$ has stabilization factor of $\beta$-phase in the range of $0.96-1.07$, and also, the same as the alloys considered above, is subjected to hardening as a result of influence of thermal cycle of welding.

After EBW in the weld metal and HAZ of alloy $\quad \mathrm{Ti}-6.5 \mathrm{Al}-3 \mathrm{Mo}-2.5 \mathrm{~V}-4 \mathrm{Nb}-1 \mathrm{Cr}-1 \mathrm{Fe}-$ $2.5 \mathrm{Zr}$ the metastable $\beta$-phase (Figure $3, a$ ) is observed with equiaxial grains, elongated in the direction of heat dissipation. Furthermore, both along the boundaries of $\beta$-grains and in the volume of grain the local accumulations of metastable $\alpha$-phase are observed in form of very dispersed spot precipitates. To relieve the welding stresses and stabilize the structure of joint after EBW both annealing, as well as local electron beam heat treatment (LHT) was performed, which consisted in postweld heating of the welded joint zone by electron beam, temperature of heating zone was maintained at level of $850{ }^{\circ} \mathrm{C}$ during $5 \mathrm{~min}$. The annealing at $800{ }^{\circ} \mathrm{C}$ with a delayed cooling resulted in decay of metastable $\alpha$ - and $\beta$-phases, observed in welding, with the formation of dispersed $\alpha$ - and $\beta$-particles, the values of impact toughness at that grow negligibly.
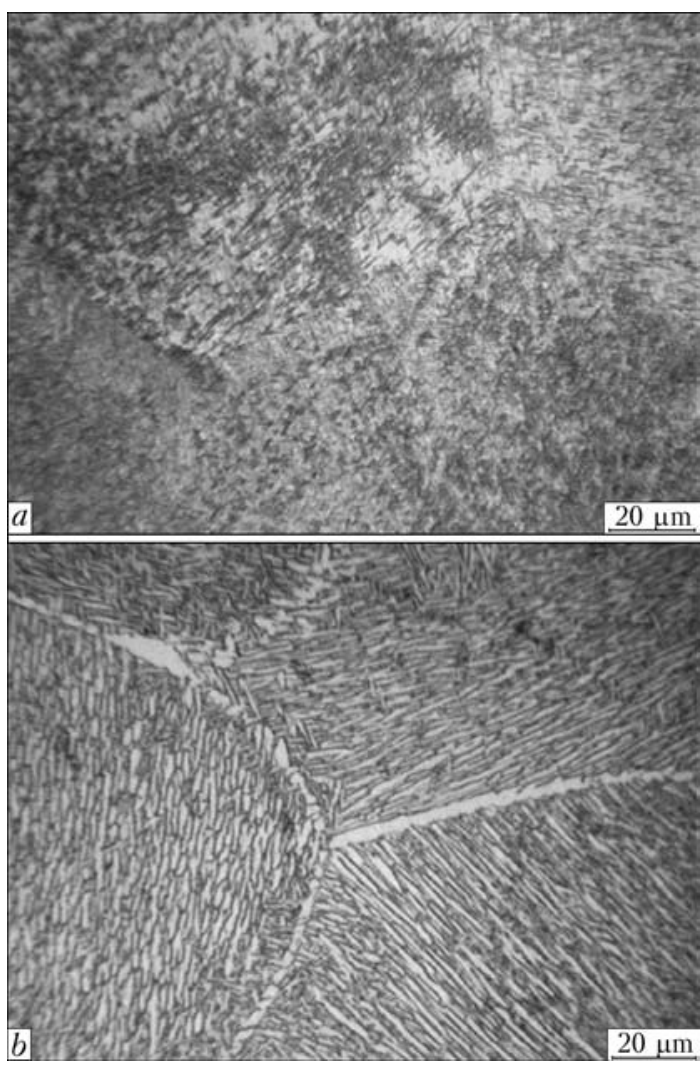

Figure 4. Microstructure of weld metal of alloy $\mathrm{Ti}-6.5 \mathrm{Al}-$ $3 \mathrm{Mo}-2.5 \mathrm{~V}-4 \mathrm{Nb}-1 \mathrm{Cr}-1 \mathrm{Fe}-2.5 \mathrm{Zr}$ produced by EBW after LHT $(a)$ and annealing at $900{ }^{\circ} \mathrm{C}(b)$

The study of mechanical properties of EBwelded joints of alloy $\mathrm{Ti}-6.5 \mathrm{Al}-3 \mathrm{Mo}^{-}-2.5 \mathrm{~V}-$ $4 \mathrm{Nb}-1 \mathrm{Cr}-1 \mathrm{Fe}-2.5 \mathrm{Zr}$ with the postweld LHT (Table 2) showed somewhat higher values of strength $\left(\sigma_{t}=1258 \mathrm{MPa}\right)$ and lower values of impact toughness of weld metal $(\mathrm{KCV}=$ $=7 \mathrm{~J} / \mathrm{cm}^{2}$ ), as compared to the corresponding values for welded joints in the state after furnace annealing at $900{ }^{\circ} \mathrm{C}$ during $1 \mathrm{~h}$. Evidently, this is explained by the partial decay of metastable structures in the weld metal as a result of effect of short-time LHT during $5 \mathrm{~min}$ and formation of fine acicular $\alpha$-phase as a result.

The weld metal of alloy $\mathrm{Ti}-6.5 \mathrm{Al}-3 \mathrm{Mo}-2.5 \mathrm{~V}-$ $4 \mathrm{Nb}-1 \mathrm{Cr}-1 \mathrm{Fe}-2.5 \mathrm{Zr}$ after TIG welding in the as-welded state is also composed of grains, equiaxial and elongated in the direction of heat dissipation of metastable $\beta$-phase (Figure $3, b$ ), observed at rapid cooling after welding. In the volume of $\beta$-grains and at their boundaries a small amount of dispersed precipitates of metastable $\alpha$-phase is observed. As a result of thermal cycle of welding the metastable structures were formed in the weld with predomination of $\beta$-phase content. The precipitation of dispersed particles of metastable $\alpha$-phase is observed along the boundaries of grains and subgrains, and is also observed in the body of grain both in weld as well as in HAZ metal. The metastable $\beta$-phase has a low 
Table 2. Mechanical properties of welded joints of titanium alloys

\begin{tabular}{|c|c|c|c|c|c|}
\hline \multirow{2}{*}{ Grade of alloy (welding method) } & \multirow{2}{*}{$\begin{array}{c}\text { Thickness } \\
\text { of metal, } \\
\text { mm }\end{array}$} & \multirow{2}{*}{ State of joints } & \multirow{2}{*}{$\sigma_{\mathrm{t}}, \mathrm{MPa}$} & \multicolumn{2}{|c|}{$\begin{array}{c}\text { Impact toughness } \\
K C V, \mathrm{~J} / \mathrm{cm}^{2}\end{array}$} \\
\hline & & & & $\begin{array}{l}\text { Weld } \\
\text { metal }\end{array}$ & HAZ \\
\hline VT23 (TIG) & 10 & As-welded & 1030 & 27 & 23 \\
\hline VT23 (TIG) & 10 & Annealing at $750{ }^{\circ} \mathrm{C}, 1 \mathrm{~h}$, air & 970 & 30 & 28 \\
\hline T110 (EBW) & 7 & As-welded & 1140 & 10 & 10 \\
\hline T110 (EBW) & 7 & Annealing at $750{ }^{\circ} \mathrm{C}, 1 \mathrm{~h}$, air & 1160 & 12 & 23 \\
\hline T110 (EBW) & 7 & Annealing at $850^{\circ} \mathrm{C}, 1 \mathrm{~h}$, air & 1120 & 21 & 26 \\
\hline T110 (TIG) & 7 & As-welded & 1118 & 11 & 10 \\
\hline T110 (TIG) & 7 & Annealing at $750{ }^{\circ} \mathrm{C}, 1 \mathrm{~h}$, air & 1078 & 29 & 30 \\
\hline $\mathrm{Ti}-6.5 \mathrm{Al}-3 \mathrm{Mo}-2.5 \mathrm{~V}-4 \mathrm{Nb}-1 \mathrm{Cr}-1 \mathrm{Fe}-2.5 \mathrm{Zr}(\mathrm{TIG})$ & 8 & As-welded & 960 & 5 & 5 \\
\hline $\mathrm{Ti}-6.5 \mathrm{Al}-3 \mathrm{Mo}-2.5 \mathrm{~V}-4 \mathrm{Nb}-1 \mathrm{Cr}-1 \mathrm{Fe}-2.5 \mathrm{Zr}(\mathrm{EBW})$ & 8 & As-welded & 1248 & 7 & 6 \\
\hline $\mathrm{Ti}-6.5 \mathrm{Al}-3 \mathrm{Mo}-2.5 \mathrm{~V}-4 \mathrm{Nb}-1 \mathrm{Cr}-1 \mathrm{Fe}-2.5 \mathrm{Zr}(\mathrm{EBW})$ & 8 & LHT at $850{ }^{\circ} \mathrm{C}, 5 \mathrm{~min}$ & 1258 & 7 & 14 \\
\hline $\mathrm{Ti}-6.5 \mathrm{Al}-3 \mathrm{Mo}-2.5 \mathrm{~V}-4 \mathrm{Nb}-1 \mathrm{Cr}-1 \mathrm{Fe}-2.5 \mathrm{Zr}(\mathrm{EBW})$ & 8 & Annealing at $900^{\circ} \mathrm{C}, 1 \mathrm{~h}$, air & 1131 & 12 & 13 \\
\hline
\end{tabular}

strength, therefore, TIG-welded joints have low values of strength in as-welded state, moreover, due to the presence of a significant volume fraction of metastable $\alpha$-phase, the weld and HAZ metal have also a low impact toughness (Table 2).

Thus, it is reasonable to carry out TIG welding of high-alloyed titanium alloy $\mathrm{Ti}-6.5 \mathrm{Al}-3 \mathrm{Mo}^{-}$ $2.5 \mathrm{~V}-4 \mathrm{Nb}-1 \mathrm{Cr}-1 \mathrm{Fe}-2.5 \mathrm{Zr}$ with the use of filler materials that will reduce the degree of alloying of weld metal and provide higher values of strength, ductility and impact toughness.

\section{Conclusions}

1. High-strength titanium alloy VT23 is characterized by a good weldability, in as-welded state the metastable $\beta$ - and $\alpha^{\prime \prime}$-phases are present in the weld metal and HAZ, and though the values of impact toughness of weld metal are rather high $\left(K C V=29 \mathrm{~J} / \mathrm{cm}^{2}\right.$ at $\left.\sigma_{t}=1128 \mathrm{MPa}\right)$, welded joints require the postweld heat treatment to stabilize their structure.

2. High-strength titanium alloy T110 is characterized by a good weldability in producing EBand TIG-welded joints by through penetration, and after annealing it has high values of impact toughness of the weld metal and HAZ, and strength of welded joints is at level of 0.9 of the base metal strength.

3. The TIG-welded joints of high-alloyed titanium alloy $\mathrm{Ti}-6.5 \mathrm{Al}-3 \mathrm{Mo}-2.5 \mathrm{~V}-4 \mathrm{Nb}-1 \mathrm{Cr}-$ $1 \mathrm{Fe}-2.5 \mathrm{Zr}$ have low values of impact toughness in the weld and HAZ, where the structure is formed with a predominance of metastable $\beta$ phase, and welded joints require high temperature of postweld annealing at $900{ }^{\circ} \mathrm{C}$, at which the impact toughness is twice increased.

4. The EB-welded joints of high-alloyed titanium alloy $\mathrm{Ti}-6.5 \mathrm{Al}-3 \mathrm{Mo}-2.5 \mathrm{~V}-4 \mathrm{Nb}-1 \mathrm{Cr}-$ $1 \mathrm{Fe}-2.5 \mathrm{Zr}$ with the highest ductility and impact toughness $\left(K C V=12.4 \mathrm{~J} / \mathrm{cm}^{2}, \delta_{\mathrm{s}}=12 \%\right)$ were produced after applying annealing at $900{ }^{\circ} \mathrm{C}$ during $1 \mathrm{~h}$, with the subsequent cooling in furnace.

1. Kablov, E.N. (2012) Strategic trends in development of materials and technologies of their recycling for period up to 2030. Aviats. Materialy i Tekhnologii, 8, 7-17.

2. Khorev, A.I. (2007) Theory and practice of development of titanium alloys for advanced structures. Tekhnologiya Mashinostroeniya, 12, 5-13.

3. Khorev, A.I. (2008) High-strength titanium alloy VT 23 and its application in advanced welded structures. Svarochn. Proizvodstvo, 9, 3-8.

4. Zamkov, V.M., Topolsky, V.P., Trygub, M.P. Highstrength titanium alloy. Pat. 40087 Ukraine. Publ. 16.06.2003.

5. Antonyuk, S.L., Korol, V.N., Molyar, A.G. et al. (2003) Investigation of mechanical properties of forged semi-products of experimental titanium alloy T110. Advances in Electrometallurgy, 3, 27-30.

6. Khorev, A.I., Joda, A.V., Krasnozhan, A.I. (1981) Mechanical properties and structure of EB-welded joints of VT23 titanium alloy. Svarochn. Proizvodstvo, 7, 25-26.

7. Zamkov, V.N., Topolsky, V.F., Trofimov, V.A. et al. (2005) Hardening heat treatment, mechanical characteristics and structure of T110 high-strength titanium alloy to be weld. In: Titanium-2005 in CIS, 198-208.

Received 28.05.2015 